Brit. J. industr. Med., 1949, 6, 82.

\title{
MANGANESE PNEUMONITIS FURTHER CLINICAL AND EXPERIMENTAL OBSERVATIONS
}

\author{
BY \\ T. A. LLOYD DAVIES and H. E. HARDING \\ From the Industrial Health Unit, Boots Pure Drug Co., Ltd., Nottingham, \\ and the Department of Pathology, The University, Sheffield
}

(RECEIVED FOR PUBLICATION, SEPTEMBER 29, 1948)

In 1837 Couper reported a case of manganese poisoning in a Glasgow stevedore, and accounts of the systemic effects of manganese in upwards of 250 industrial workers have appeared with increasing frequency since the 1914-18 war. The first suspicion that manganese might cause pulmonary disease was in 1921, when Brezina reported a high death rate from pneumonia in workers in a pyrolusite mill. After the opening in 1923 in Sauda, a small Norwegian town, of a works which smelted manganese ore, Elstad (1939) reported that the pneumonia rate was eight times higher in that district than in the rest of Norway. The increased pneumonia rate was associated with a pall of smoke which was emitted by the works and which consisted of dust containing manganese. Buttner (1939) observed a high incidence of deaths from pneumonia amongst Rhenish manganese miners who also suffered from silicosis as the Geissen ore contains about 20 per cent. of silica. Buttner agreed with Baader (1937) that the constant occurrence of pneumonia among manganese workers allowed of no other point of view than that manganese has a causal relation.

Because of the difficulty in reproducing the condition in animals, and from an analysis of the pneumonia rate of different groups of exposed workers, Heine (1943) doubted the direct relationship between manganese and pneumonia. Jötten and Reploh (1939) showed that though the inhalation of manganese induced pneumonia in rabbits, the presence of some other factor such as the inhalation of pneumococci or " twisting the rabbits about," in order, in the view of the authors, "to simulate extreme climatic conditions," increased the ease of production of pneumonia and its intensity. Reploh (1943) reported a similar result after mice had been exposed to the dust of manganese carbonate, dust from a Sieman-Martin's furnace containing 9 per cent. manganese, and basic slag. Though some lung changes occurred after exposure to dust alone, these were enhanced if the mice were treated with inhalation of dead pneumococci, or with dead pneumococci and live pneumococci eight days later.

Observations by Lloyd Davies (1946) showed a causal relationship of manganese to the high incidence of pulmonary disease experienced by a group of men (numbering over a period of eight years from 47 to 124) exposed to the inhalation of manganese dioxide and higher oxides of manganese. Besides a high incidence of pharyngitis, bronchitis, and bronchopneumonia, an illness commonly diagnosed as pneumonia occurred with a frequency of 26 per thousand compared with an incidence of 0.73 per thousand for pneumonia in a control group. As this illness showed slight clinical differences from pneumonia, but more especially as manganese affected the whole respiratory tract from the nose to the alveoli, the term manganese pneumonitis was suggested.

Environmental studies in the works showed that high total particle counts were frequent; very commonly dust counts (determined by the thermal precipitator) in the region of 5,000 particles and occasionally counts as high as 20,000 or more particles per c.cm. of air were obtained.

In all counts 90 per cent. of the particles were less than $1 \mu$, and nearly always 80 per cent. of particles were less than $0.2 \mu$. Calculation of the mass concentration gave results which differed widely from the mass concentration determined by the electrostatic precipitator (Lloyd Davies, 1946). Six estimations of the dust present in the air by the electrostatic precipitator gave concentrations of $0 \cdot 42,0 \cdot 7,7 \cdot 9,9 \cdot 2,37 \cdot 3$, and $38.3 \mathrm{mg}$. of dust in one cubic metre of air. The corresponding manganese dioxide content of the dust was $41,43,66,65,58$, and 54 per cent. Flinn and others (1940), who observed thirty-four men working in a manganese ore-crushing plant, found no case of manganese 
poisoning in nine men exposed to less than $30 \mathrm{mg}$. of manganese per cubic metre (though two had been exposed for less than a year). Of ten men exposed to inhalation of "manganese"* in concentrations of $90 \mathrm{mg}$. per cubic metre, five suffered from poisoning. Five out of six men suffered from poisoning after more than three years, and three out of four men after less than three (but more than one) years' exposure. Fifteen men were exposed to intermediate concentrations, and three were affected, though the varying work of each made exact determination of the risk difficult.

Under the conditions of the experiment mice exposed by Lloyd Davies (1946) to dust of manganese dioxide did not show an increased susceptibility to Pneumococcus type II or IV or to Streptococcus hamolyticus (Richards), even though marked toxic effects, due to manganese, were present. A characteristic monocytic reaction constantly occurred in the lungs of exposed mice.

\section{Clinical Observations}

Table 1 is a continuation of Table 1 in Lloyd Davies' original communication (1946) and shows

${ }^{*}$ Though Flinn and his collaborators do not specify the form in which manganese was estimated, it was probably as manganese dioxide. that the high incidence of manganese pneumonitis has been maintained.

In four cases of pneumonitis or pneumonia occurring in 1946 to 1948 the sputum or nasopharyngeal swabs were examined with the results shown in Table 2.

Though all patients were treated by chemotherapy, and the consequent alteration of the bacteriological flora of the sputum and nasopharynx makes interpretation of the result equivocal, it seems unlikely, with the exception of Case 3, that bacterial infection played a primary role in producing the consolidation unquestionably present in the lung.

\section{Animal Experiments}

Manganese in the form of manganese dioxide dust and of solutions of manganese chloride was introduced into the lungs of rats to determine (a) the histological changes developing over a period of time after the introduction of manganese dioxide, and $(b)$ the immediate effect of manganese dioxide and chloride on the bronchial and alveolar epithelium.

\section{Technique}

A series of rats had manganese introduced into their lungs by intratracheal injection. Under ether anæs-

TABLE 1

INCIDENCE OF PNEUMONITIS

\begin{tabular}{|c|c|c|c|c|c|c|c|c|c|}
\hline \multirow[t]{2}{*}{ Year } & \multicolumn{3}{|c|}{ Manganese Plant } & \multicolumn{3}{|c|}{$\begin{array}{l}\text { Health Insurance Society. } \\
\text { Males } 21-65 \text { years }\end{array}$} & \multicolumn{2}{|c|}{$\begin{array}{l}\text { England and } \\
\text { Wales }(b)\end{array}$} & \multirow{2}{*}{$\begin{array}{c}\text { U.S. } \\
\text { Public } \\
\text { Health } \\
\text { Report } \\
\text { Wash- } \\
\text { ington }(e) \\
\\
\text { Pneu- } \\
\text { monia } \\
\text { rate per } \\
1,000 \\
\text { males }\end{array}$} \\
\hline & $\begin{array}{c}\text { Maximum } \\
\text { number } \\
\text { employees } \\
\text { (at end) } \\
\text { of any } \\
\text { quarter) }\end{array}$ & $\begin{array}{l}\text { Number } \\
\text { of cases } \\
\text { of "pneu- } \\
\text { monia" }\end{array}$ & $\begin{array}{c}\text { "Pneu- } \\
\text { monia," } \\
\text { rate per } \\
1,000 \\
\text { employees }\end{array}$ & $\begin{array}{l}\text { Number } \\
\text { of male } \\
\text { members }\end{array}$ & $\begin{array}{l}\text { Number } \\
\text { first } \\
\text { certificate } \\
\text { of pneu- } \\
\text { monia }\end{array}$ & $\begin{array}{l}\text { Pneu- } \\
\text { monia } \\
\text { rate per } \\
1,000 \\
\text { members }\end{array}$ & $\begin{array}{l}\text { Number } \\
\text { reported } \\
\text { cases of } \\
\text { pneu- } \\
\text { monia }(c)\end{array}$ & $\begin{array}{l}\text { Pneu- } \\
\text { monia } \\
\text { rate per } \\
1,000 \\
\text { popula- } \\
\text { tion }(d)\end{array}$ & \\
\hline $\begin{array}{c}1938 \\
1939 \\
1940 \\
1941 \\
1942 \\
1943 \\
1944 \\
1945 \\
1946 \\
1947 \\
1948 \\
\text { to date }\end{array}$ & $\begin{array}{r}47 \\
40 \\
67 \\
101 \\
124 \\
101 \\
70 \\
75 \\
94 \\
99 \\
-\end{array}$ & $\begin{array}{l}3 \\
2 \\
1 \\
3 \\
3 \\
2 \\
0 \\
2 \\
1(f) \\
3(g) \\
1\end{array}$ & $\begin{array}{r}63 \\
50 \\
15 \\
30 \\
24 \\
20 \\
0 \\
26 \\
10 \\
30 \\
-\end{array}$ & $\begin{array}{c}5991 \\
6342 \\
6586 \\
6678 \\
6751 \\
4899(a) \\
5008(a) \\
4645(a) \\
4430(a) \\
- \\
-\end{array}$ & $\begin{array}{l}3 \\
3 \\
6 \\
4 \\
6 \\
6 \\
5 \\
1 \\
0 \\
\text { Not av } \\
-\end{array}$ & $\begin{array}{c}0.52 \\
0.47 \\
0.91 \\
0.59 \\
0.89 \\
1.20(a) \\
1.00(a) \\
0.02(a) \\
0.00 \\
\text { ilable } \\
-\end{array}$ & $\begin{array}{c}-\overline{312} \\
47,875 \\
50,942 \\
42,698 \\
52,407 \\
38,631 \\
34,412 \\
36,688 \\
-\end{array}$ & $\begin{array}{l}-1 \cdot 0 \\
1 \cdot 2 \\
1 \cdot 2 \\
1.0 \\
1 \cdot 2 \\
0.9 \\
0.8 \\
0.9 \\
-\end{array}$ & $\begin{array}{l}- \\
\bar{z} \\
3 \cdot 8 \\
3 \cdot 5 \\
- \\
- \\
- \\
-\end{array}$ \\
\hline
\end{tabular}

(a) Civilians only.

(b) Summary Report by the Ministry of Health, 1942, and Annual Report H.M. Stationery Office.

(c) Males and females (all ages, including non-civilians).

(d) Pepulation (estimated mid-year 1939) 41,460,000 (note, after 1939 statistics and estimates exclude non-civilian males).

(e) Public Health Report, 1943. Washington.

(f) One other case, not included in the Table, occurred in a man recovering and drying manganese dioxide in another plant.

(g) One patient developed heart failure and auricular flutter (see Table 2, Case 3). 
thesia the trachea was exposed and a suspension of manganese dioxide dust (particle size, 80 per cent. of particles less than $1 \mu$ ), $10 \mathrm{mg}$. in $1 \mathrm{ml}$. normal saline was injected into the lungs through a fine needle inserted between the rings of the trachea. As previous work suggested that the immediate effect may depend on solution of manganese in tissue fluids, $1 \mathrm{ml}$. of 5 per cent. and of 0.5 per cent. solutions ( $p \mathrm{H} \mathrm{6.3)}$ of manganese chloride in normal saline was injected into other animals. Animals were sacrificed at varying intervals, from one hour to eighteen months in the case of rats injected with manganese dioxide, and from a few minutes to eight days in rats injected with manganese chloride. After anæsthetization by ether, the trachea was tied during inspiration and the animal killed by cutting the abdominal aorta. The lungs were removed in an inflated condition and preserved in formol saline. To examine the bronchial and alveolar epithelium, the animal was killed with ether, and the lungs were removed immediately after death and distended by running a mixture of equal parts of formol saline and a saturated watery solution of mercuric chloride into the trachea under about $5 \mathrm{~cm}$. pressure. Paraffin sections were stained with Ehrlich's acid hæmatoxylin and eosin, with Weigert's elastin stain and Van Gieson, and by Wilder's modification of Foot's method for reticulin : frozen sections were stained with Scarlach R. One of us (H.E.H.) reported on the histological sections without knowing the experimental details of the animals, all of which were injected by the other (T.A.L.D.) in the Research Department, Boots Pure Drug Co. Ltd. Reports were subsequently placed in their proper time relationship and found to form a series showing progressive changes. In all, seventy rats were injected and their lungs examined.

\section{Results}

After the injection of manganese dioxide,* areas of the lung varying in size and position according to the distribution of injected suspension were stained black and consolidated. Emphysema

* After the intratracheal injection of normal saline ( $p \mathrm{H} \mathrm{6 \cdot 5)} \mathrm{using}$ the above techniques, the lungs of rats appeared normal and did not show any histological abnormalities.

TABLE 2

BACTERIOLOGICAL EXAMINATION OF NOSE, THROAT, AND SPUTUM

\begin{tabular}{|c|c|c|c|}
\hline $\begin{array}{l}\text { Year } \\
\text { and } \\
\text { Case } \\
\text { No. }\end{array}$ & $\begin{array}{l}\text { Interval between } \\
\text { onset of illness } \\
\text { and examination } \\
\text { (days) }\end{array}$ & Result & Remarks \\
\hline $\begin{array}{c}1946 \\
\text { (1) }\end{array}$ & 4 & $\begin{array}{c}\left.\begin{array}{c}\text { Throat } \\
\text { Nose }\end{array}\right\} \begin{array}{l}\text { Staph. albus and diphtheroid bacilli ; } \\
\text { slightly haemolytic Gram-negative } \\
\text { cocco-bacillus, probably } H \text {. influ- } \\
\text { enzae. }\end{array} \\
\text { Sputum : } \\
\text { Culture : }\end{array}$ & $\begin{array}{l}\text { Own doctor's diagnosis, broncho- } \\
\text { pneumonia }\end{array}$ \\
\hline $\begin{array}{c}1947 \\
(2)\end{array}$ & 9 & $\begin{array}{ll}\text { Throat : } & \\
\text { Direct film : } & \text { No pneumococci. } \\
& \text { Strep. pyogenes. } \\
\text { Culture : } & \text { No pneumococci. }\end{array}$ & $\begin{array}{l}\text { Admitted to Nottingham General } \\
\text { Hospital. Diagnosed lobar } \\
\text { pneumonia. } X \text {-ray patches of } \\
\text { increased density throughout } \\
\text { left lung. Appearance suggests } \\
\text { pneumonia with considerable } \\
\text { pleural involvement. }\end{array}$ \\
\hline $\begin{array}{c}1948 \\
(3)\end{array}$ & 10 & $\begin{array}{l}\text { Many pneumococci. } \\
\text { Staph. albus; Gram negative bacilli. } \\
\text { No pneumococci. } \\
\text { Staph. albus. }\end{array}$ & $\begin{array}{l}\text { Own doctor's diagnosis, atypical } \\
\text { pneumonia, later developed } \\
\text { heart failure with auricular } \\
\text { fibrillation. }\end{array}$ \\
\hline $\begin{array}{l}1948 \\
(4)\end{array}$ & 4 & $\begin{array}{ll}\begin{array}{l}\text { Sputum : } \\
\text { Direct film : }\end{array} & \begin{array}{l}\text { Numerous organisms and few } \\
\text { leucocytes. }\end{array} \\
\text { Culture : } & \text { Strep.haem. Staph. pyogenes. } \\
& \text { Staph. albus. Strep. haemolyticus. } \\
& \text { M. Catarrhalis. } \\
\text { Sarcinae. Pneumococci. } & \\
\text { Typing of pneumococci : } & \\
\text { The strain failed to give any agglu- } \\
\text { tination or precipitation reaction } \\
\text { with anti-pneumococcal serum } \\
\text { types I, II, and III. }\end{array}$ & $\begin{array}{l}X \text { ray of lungs : area of consolida- } \\
\text { tion right lower lobe. }\end{array}$ \\
\hline
\end{tabular}




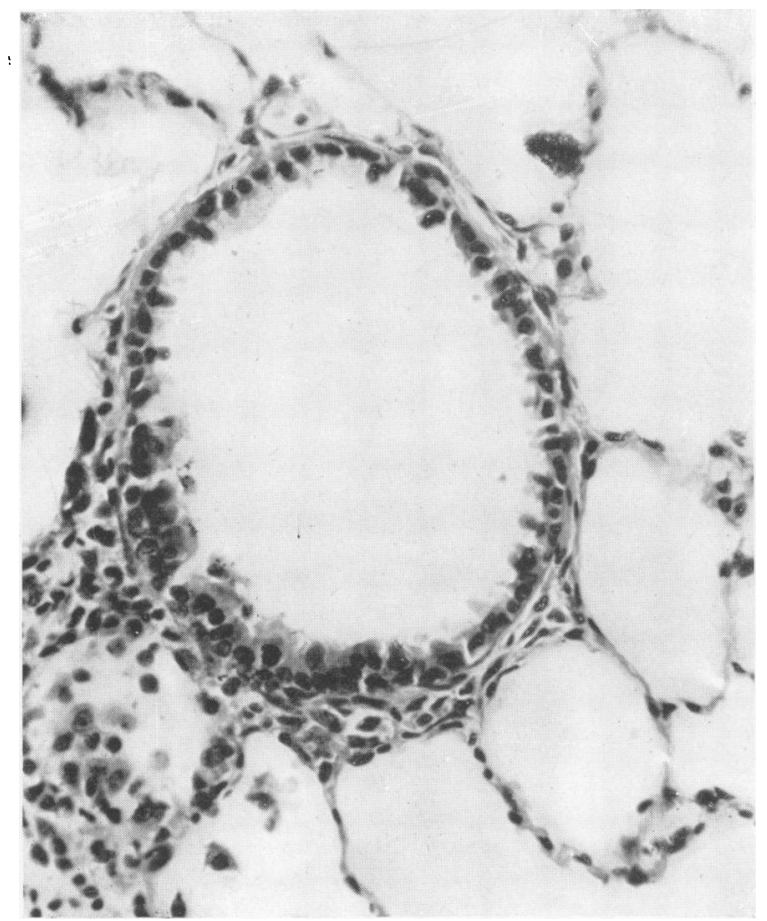

FIG. 1

FIG. 1.-Section of lungs of Rat 257, one hour after intratracheal injection of manganese dioxide dust. Alveoli are not evidently abnormal. Mucosa of bronchi (especially smaller bronchi) very ragged. Many cells have lost their supranuclear cytoplasm. $\times \mathbf{3 5 0}$.

Fig. 2.-Section of lungs of Rat 10, four hours after intratracheal injection of manganese dioxide dust, showing irregular thickening of alveolar walls with mononuclear-cell infiltration and a few large hydropic cells. Bronchi (not shown) appeared normal. $\times 750$.

FIG. 3.-Section of lungs of Rat 258, six hours after intratracheal injection of manganese dioxide dust, showing ragged bronchial mucosa. Cellular accumulation around terminal bronchi. $\times 500$.

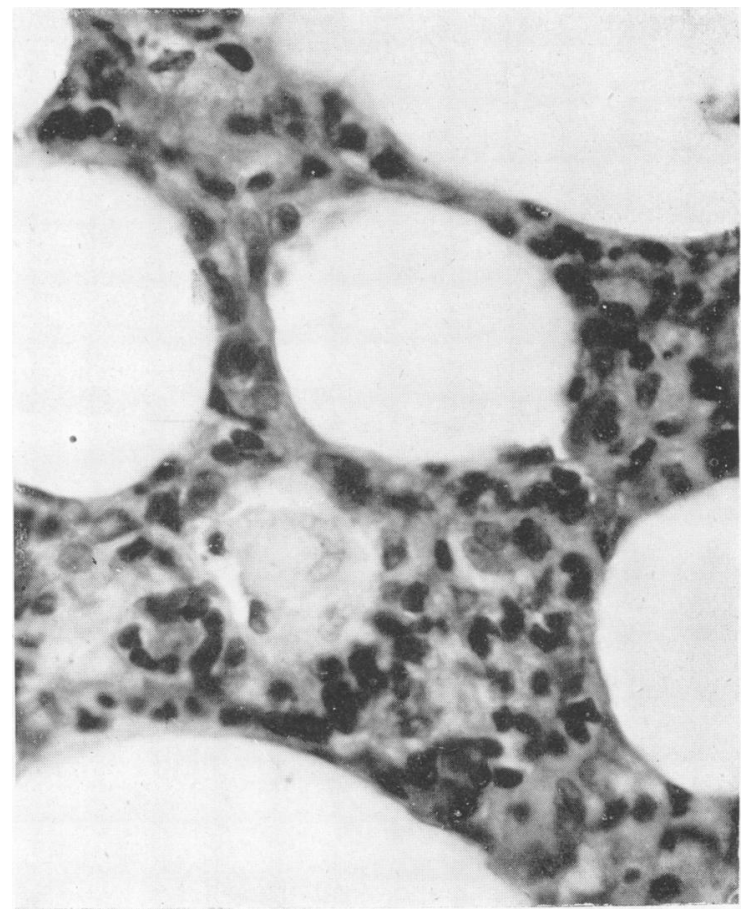

FIG. 2

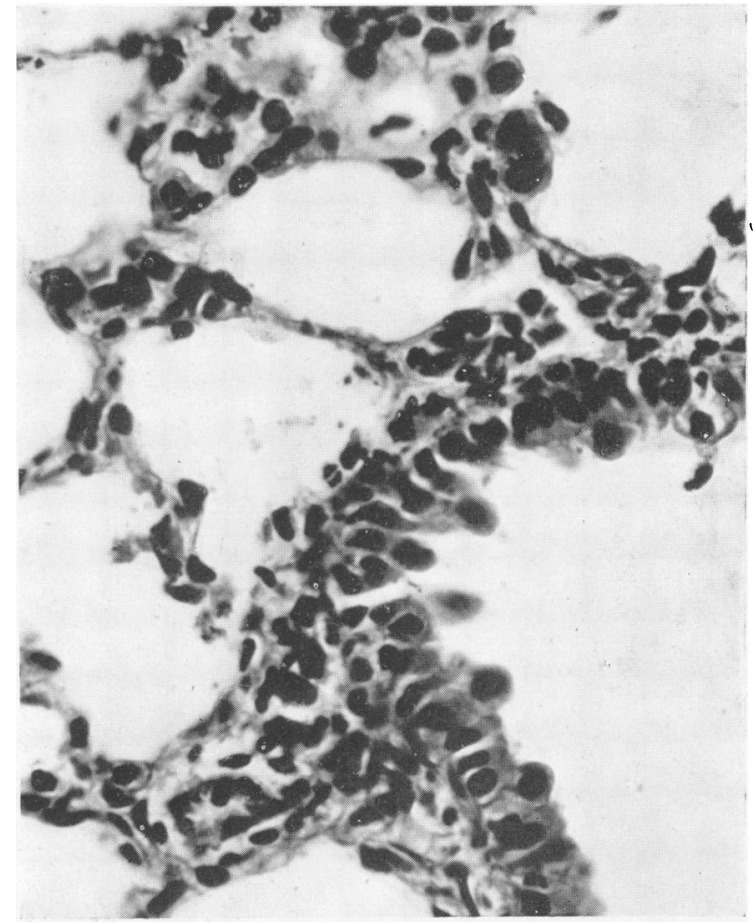

FIG. 3 


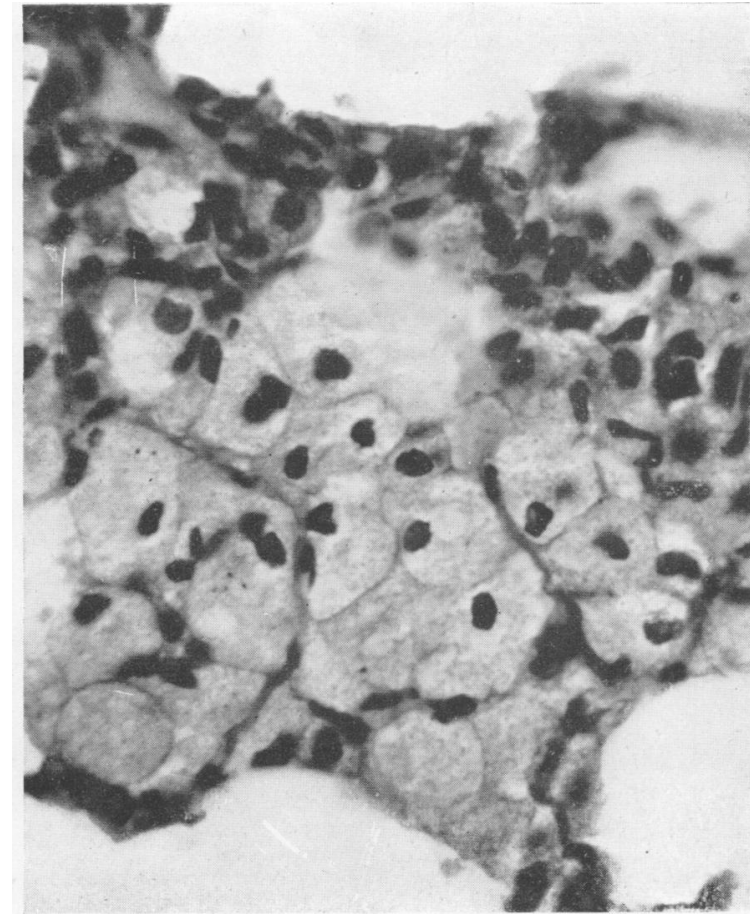

Fig. 4.- Section of lungs of Rat 1, twelve hours after intratracheal injection of manganese dioxide dust, showing mononuclear infiltration and many large hydropic cells filling adjacent alveoli. $\times 750$.

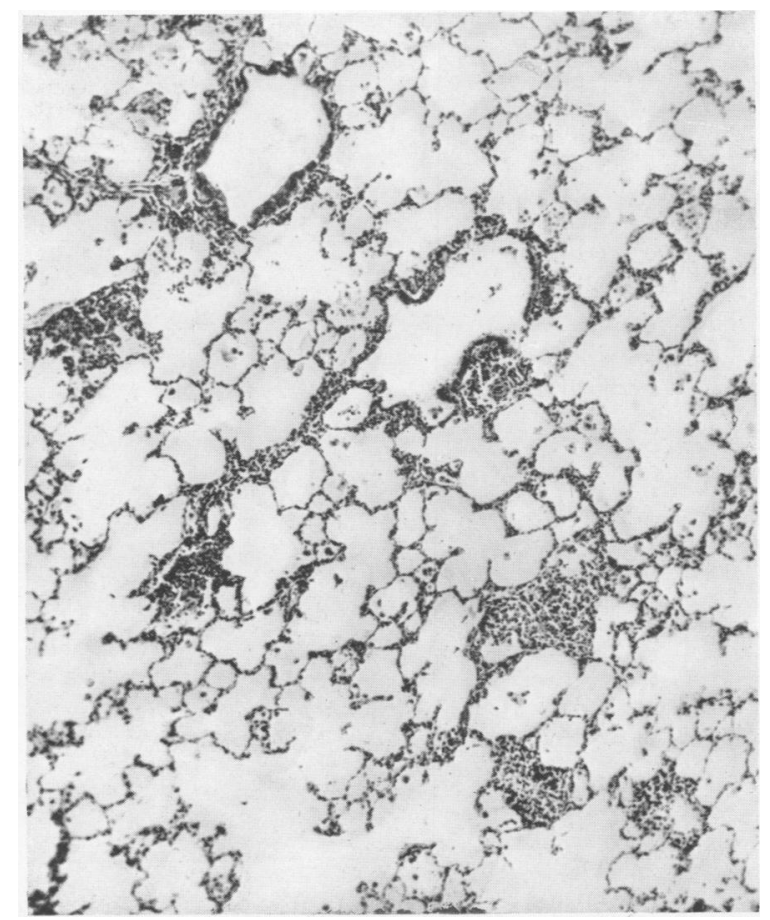

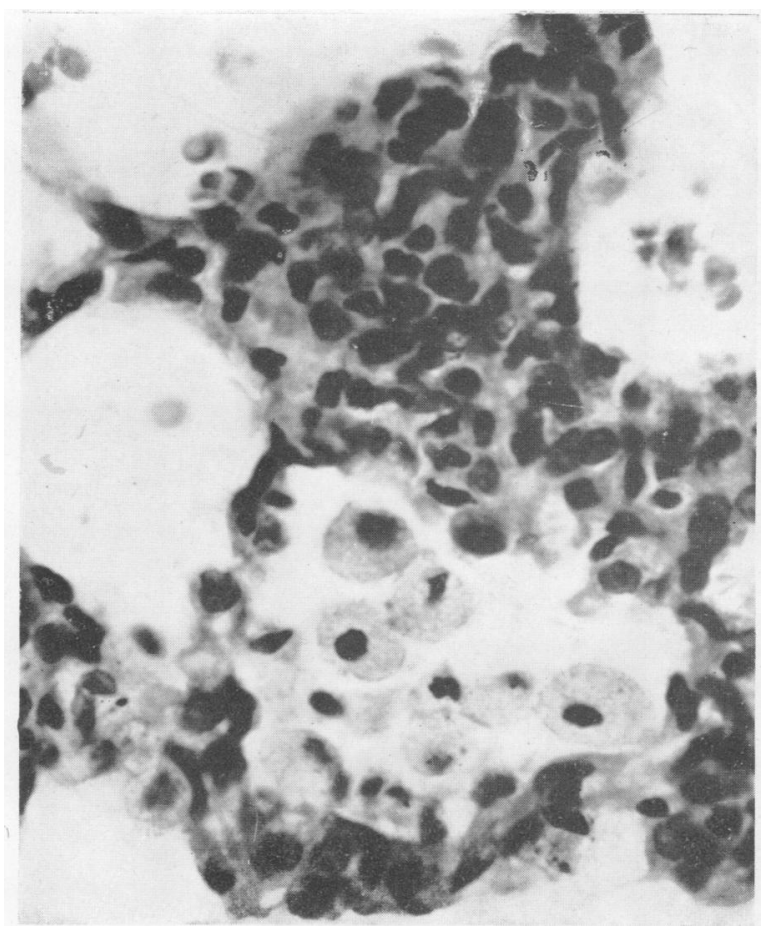

FIG. 5.-Section of lungs of Rat 5, seven days after intratracheal injection of manganese dioxide dust, showing similar changes to Figs. 2 and 4 . Note mononuclearcell reaction with no polymorphs. Alveoli filled with granular precipitate of protein (difficult to see in photograph). $\quad \times 750$.

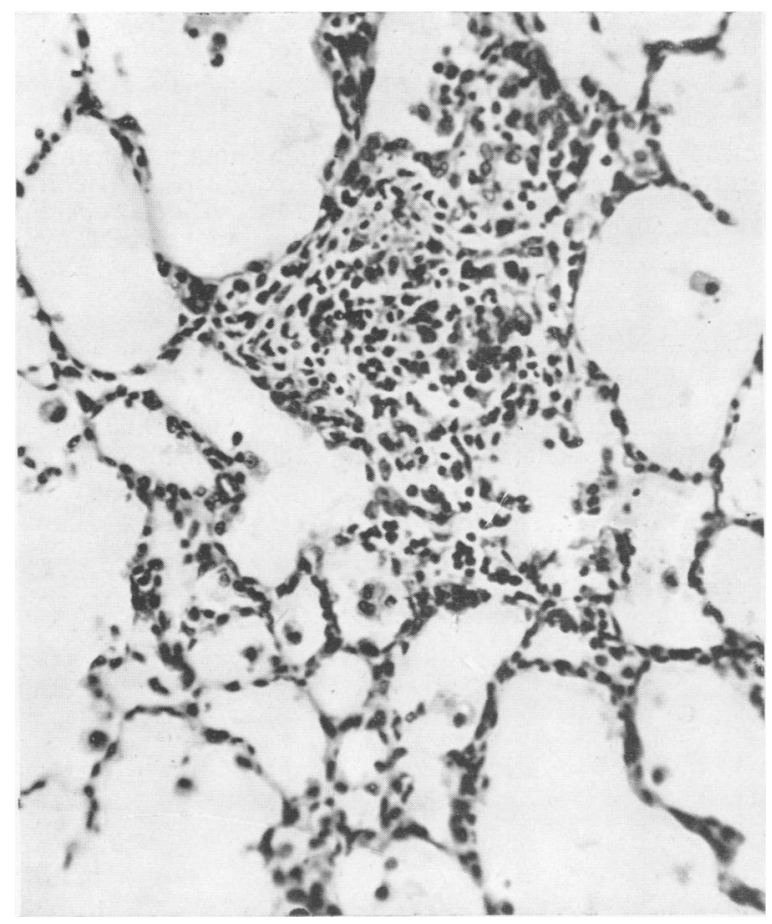

FIgS. 6 and 7.-Section of lungs of Rat 262, fourteen days after intratracheal injection of manganese dioxide dust. Granular protein precipitate in alveoli, with mononuclear histiocytes (some with vacuolated cytoplasm) and large hydropic cells in alveoli. Suggestion of granulomatous follicles. Fig. 6 (left) $\div 40$ and Fig. 7 (right) $<250$. 


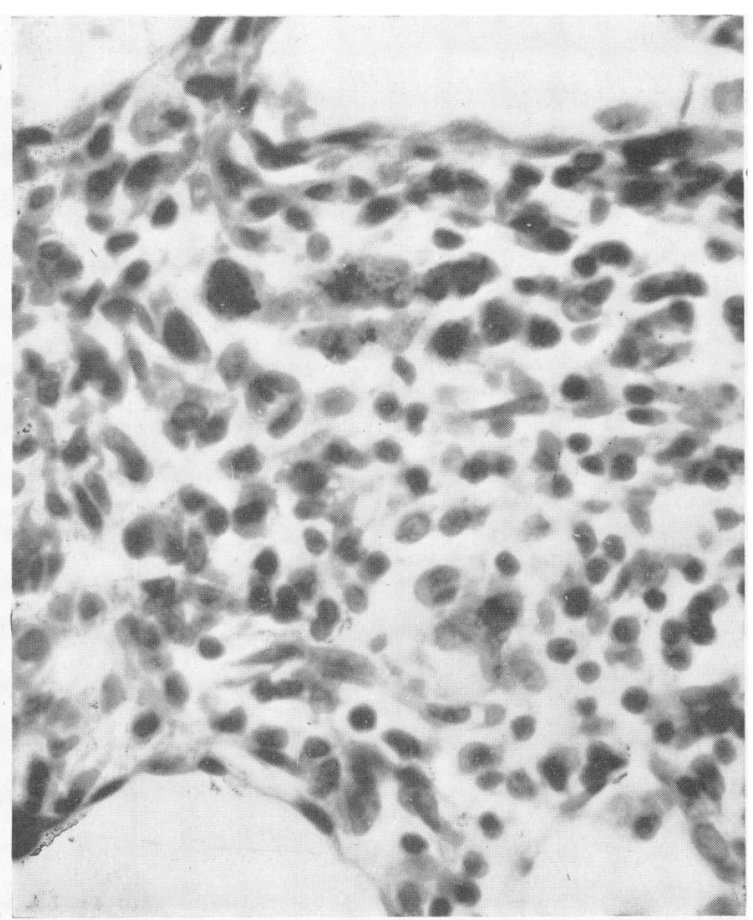

Fig. 8.- Section of lungs of Rat 263, twenty-nine days after intratracheal injection of manganese dioxide dust, showing granuloma with pigment filled histiocytes. $\times 750$.

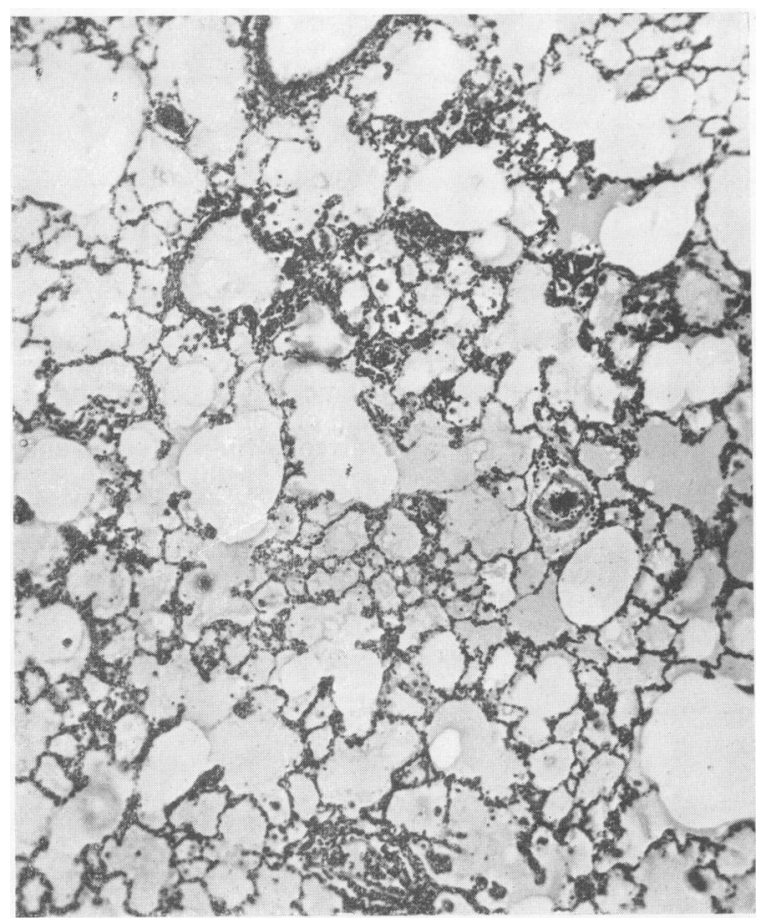

FIGS. 10 and 11.--Section of lungs of Rat 253, one hour after intratracheal injection of 0.5 per cent. manganese chloride solution. Alveoli contain eosinophilic coagulum showing occasional fibrils. Early cellular reaction (mostly mononuclear) at point where bronchi communicate with alveoli. Epithelium of bronchi covered by layer of mucus or balls of mucus ; cells not evidently damaged. Fig. 10 (left) $\times 40$ and Fig. 11 (right) $\times 500$. 

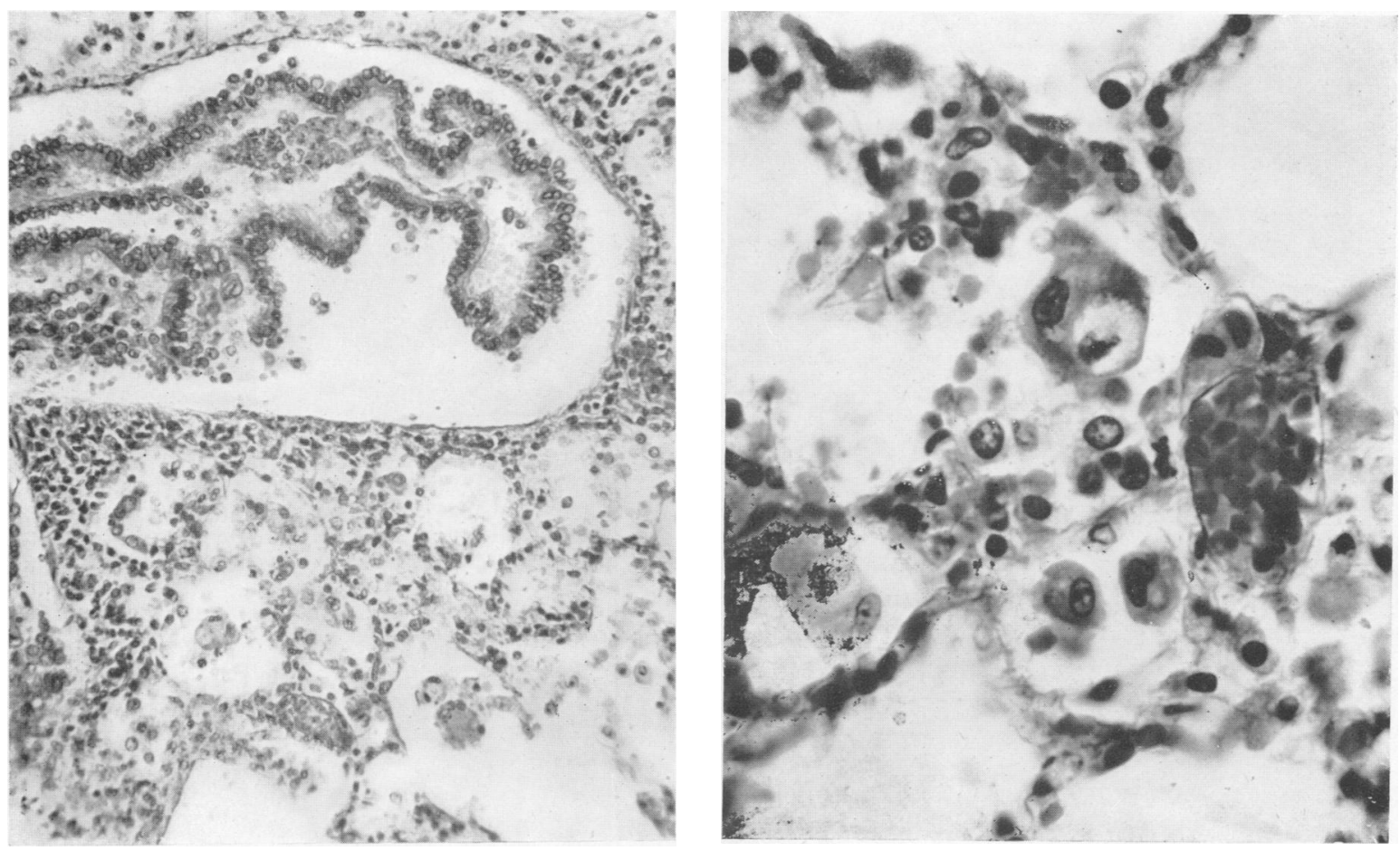

Figs. 12 and 13.-Section of lungs of Rat 286 twelve hours after intratracheal injection of 0.5 per cent. manganese chloride solution. Most of the bronchial epithelium is detached from its basal membrane and lies coiled in the lumen. Alveoli contain a pale staining granular or fibrillar precipitate, and most contain one or more histiocytes. A few alveoli contain large hydropic cells. Red cells and debris are also present in the alveoli. Fig. $12 \times 250$ and Fig. $13 \times 750$. 
appeared after a few hours. Histological examination shows that within fifteen minutes of contact with manganese dioxide the bronchial epithelial cells discharge their mucus, and their supranuclear cytoplasm shrinks and in some cases appears to be shed ; the mucosa, even at this early stage, has a very ragged appearance, with globules of mucus and portions of cytoplasm adhering irregularly to the surface. A little later shedding of the individual epithelial cells occurs, and short lengths of mucosa show loosening from the basal membrane. At this stage the alveoli show irregular inflammatory thickening of the walls. About twenty-four hours later a histiocytic (mononuclear) reaction appears in the interstitial tissue and the alveoli contain many histiocytic cells. This is characteristic of manganese. After four to six hours large hydropic cells with the nucleus pushed to one side by swollen cytoplasm containing fat droplets begin to appear ; after two days these cells may be pesent in large numbers. They are not specific to manganese as they appear after injection of silica, beryllium oxide, nickel oxide, and cobalt oxide, though in far fewer numbers. Similar cells occur in cats' lungs after the injection of suspension of manganese dioxide dust. Later wide-spread bronchopneumonia may develop and there may be a polymorph reaction. (The introduction of bacterial infection, either with the injection or secondarily, cannot be excluded.) Nevertheless, even in the case where a polymorph reaction does occur, the histiocytic reaction remains intense. At this stage the bronchial mucosa appears taller and has become less abnormal. Inconstant appearances after the injection of manganese are an early granulomatous reaction after a fortnight and phagocytic giant cells six weeks later.

After the injection of 5 per cent. solutions of manganese chloride all animals died of gross pulmonary œdema within a few minutes. The lungs were intensely congested, but histological examination showed nothing abnormal. Within an hour after injection of $1 \mathrm{ml}$. of 0.5 per cent. manganese chloride ( $p H$ 6.3) one third of the animals died from pulmonary œdema with a thin, watery fluid exuding in large quantities from their mouths. The lungs of animals dying or killed at this time are intensely congested. On histological examination the lungs of animals dying or killed a few hours later, show a protein precipitate in the alveoli, appearing mainly as a homogeneous eosinophilic coagulum but partly as a granular or slightly fibrillar precipitate. There is some proliferation of cells that appear to be histiocytes in the walls of the terminal bronchi and atria. The bronchial epithelium is cubical, the cells having discharged all their mucus. Animals killed or dying several hours later show rather less protein precipitate in the alveoli, which also contain a few histiocytes and, rarely, one or two polymorphs : the accumulation of cells is more marked in the region of the terminal bronchi. The bronchial epithelium appears disorganized, and much of it may be detached from the basal membrane and may be lying curled up in the lumen. Mucus and balls of epithelial cells cover part of the bronchial epithelium. In animals killed a week after injection the alveoli appear normal, but the mucosal cells of the small bronchi are still abnormal and contain less than the normal quantities of mucus ; and some of them are being shed.

\section{Discussion}

The results reported here differ from those of Continental workers as both in men and in animals manganese caused intense pulmonary irritation without the presence of other factors. Unlike Continental workers, who constantly report toxic symptoms, no case of systemic manganese poisoning was seen in spite of the closest watch.

In the group of workers observed by Lloyd Davies (1946) the particle size of the dust was very fine; though the amount of manganese dioxide present in the air was determined on only seven occasions, the concentration was relatively low. The high particle count and low mass concentration is accounted for by the fact that the mass of a sphere or particle of dust assumed to be a sphere increases in proportion to the cube of the radius ; for example, 20,000 particles of manganese dioxide $1 \mu$ in diameter have the same mass as 20 particles $10 \mu$ in diameter. For this reason the workers observed by Lloyd Davies did not absorb a sufficient quantity of manganese to cause systemic poisoning, but because of their fineness the particles were particularly liable to give rise to pulmonary effects. Continental workers report neither studies of working conditions nor the number and size of particles of manganese dust present in the air.

Therein lies the source of confusion. No doubt if the particle size of the dust is larger, as is probable in the cases observed by Continental workers because of consistent reports of systemic poisoning, the chance of intimate contact with the epithelium and therefore of pulmonary symptoms will be less. In these circumstances, some other factor such as exposure to abnormal climate or bacteria, may be required to produce " pneumonia." The possibility of atypical pneumonia or virus pneumonia occurring in workers subject to the present observations cannot be entirely excluded. The constant occurrence of manganese pneumonitis, year after year, 
and the clearly demonstrated irritant action of manganese in animal experiments in whom no suggestion of virus infection arises, renders this explanation very unlikely. The present series of animal experiments in which manganese was injected into the lungs of rats confirms that manganese is irritant to the bronchial and alveolar epithelium and causes a characteristic mononuclear-cell reaction. The intensity and nature of this reaction is unlike that seen after the injection of other dusts employed by us. Large hydropic cells constantly occur in large numbers after the introduction of manganese into the lungs of rats ; less constantly, and in far fewer numbers, similar cells occur after the introduction of other dusts. Probably the presence of hydropic cells is related to the degree of tissue irritation produced by chemical agents. Further work on the significance of these cells is in progress. Histological appearances after the injection of manganese dioxide and manganese chloride into the lungs of rats leave no doubt that manganese causes a specific and characteristic cellular reaction, resulting in gross consolidation. Apart from the occasional accidental introduction of infection, no other factor is or can be operating. The conclusion is justified that, in man and animals, manganese dust in suitable particle size introduced into the respiratory system will, without the presence of other factors, cause pneumonitis.

\section{Summary}

Pneumonitis has continued to affect men exposed to the inhalation of dust containing manganese dioxide and the higher oxides of manganese. The intratracheal injection of suspensions of manganese dioxide in normal saline and solutions of manganese chloride in normal saline into the lungs of rats causes characteristic histological changes. Within fifteen minutes of contact with manganese dioxide the epithelial cells of the bronchi discharge their mucus and the epithelium becomes ragged and may be loosened from the basal membrane. An intense mononuclear-celled infiltration of the alveolar walls and alveoli develops after about twentyfour hours, and shortly after this large hydropic cells appear, often in large numbers. Late and inconstant changes are a granulomatous reaction and giant-cell formation. After about a year these changes have disappeared and the lung appears normal. The injection of manganese chloride causes intense congestion of the lung; many animals die from pulmonary œdema. The bronchial epithelium is disorganized and often detached, but compared with the effect of manganese dioxide the histiocytic (mononuclear) infiltration of the alveoli is less intense.

In man and animals, manganese dust in suitable particle size introduced into the respiratory system will, without the presence of other factors, cause pneumonitis.

We are indebted to Miss E. Wilkinson and Miss E. Parker for technical assistance in many tedious experiments and to Mr. T. C. Dodds for the photomicrographs.

Drs. Furness, Hay-Heddle, Hill, and O'Donovan have kindly allowed one of us (T.A.L.D.) to examine patients in their care.

\section{REFERENCES}

Baader, H. W. (1937). Arztl. Sachverst., Ztg. 6.

Brezina, E. (1921). "Internationale ubersicht über Gewerbe krankleiten." Springer. Berlin. Quoted by Vigliani, E. C. (1937). Folia Med., 23, 457

Buttner, H. E. (1939). " Report on the Eighth International Congress for Industrial Accidents and Occupational Disease," 2, 1022. Leipzig.

Couper, J. (1837). Brit. Ann. Med., 1, 41.

Elstad, D. (1939). "Report on the Eighth International Congress for Industrial Accidents and Occupational Disease," 2, 1028. Leipzig.

Flinn, R. H., Neal, P. A., Reinhart, W. H., and Dalavalle, J. M. (1940). U.S. Publ. Hlth. Serv. Bull., No. 247.

Heine, W. (1943). Z. Hyg. Infektionskr., 125, 3.

Jötten, K. W., and Reploh, H. (1939). "Report on the Eighth International Congress for Industrial Accidents and OccupaInternational Congress for Indust

Lloyd Davies, T. A. (1946). Brit. J. industr. Med., 3, 111.

Reploh, H. (1943). Arch. Hyg. Bakt., 131, 16. 